\title{
PENGARUH MODIFIKASI ATRAKTAN TERHADAP JUMLAH TELUR NYAMUK Aedes sp YANG TERPERANGKAP DI KELURAHAN KARANGPUCUNG KECAMATAN PURWOKERTO SELATAN KABUPATEN BANYUMAS TAHUN 2014
}

\author{
Sovi Milasari *), Mela Firdaust, SST **)
}

Abstract

Millennium Development Goals (MDGs), which is about illuminating the sixth goal of HIV / AIDS, malaria and other infectious diseases. One infectious disease is a disease of Dengue Hemorrhagic Fever (DHF). The purpose of this study is to determine the effect of the modification attractant the number of eggs of Aedes sp Karangpucung trapped in the Village, District of Purwokerto Selatan Banyumas 2014.

Pre-experimental research design is, this research design using the static group comparison design. Determining sampling at this research using inclusion criteria. 5 study subjects DHF cases in 2013 were located in the Village. Karangpucung. Data accumulation techniques is by using questionner. Data analysis using Kruskall Wallis test as an alternative to One Way Anova test.

Kruskal-Wallis statistical test results obtained $p=0.007 \leq \alpha \quad 0,05$ mean there is a significant difference between the number of eggs of Aedes $s p$ trapped in each attractant. Then followed each test group differences using nonparametric analysis with the $U$ Mann Whitney test groups 1 and 2 are significant $(p=0.631)$ meaning that there is no difference, groups $1 \& 3$ and 2 \& 3 groups was significant $(p=0.009)$ means there different.

In conclusion, the effect of the modification there isattractant against Aedes sp Karangpucung trapped in the Village District of Purwokerto Selatan Banyumas 2014. Suggestion submitted to the community should play an active role in the activities PSN Plus 3M.

References : :38 (2004-2014)

Keywords : : Aedes sp, type attractant

Classification : Vector Control

*) Alumni Mahasiswa Jurusan Kesehatan Lingkungan Purwokerto

${ }^{* *}$ ) Dosen Jurusan Kesehatan Lingkungan Purwokerto

\section{PENDAHULUAN}

\section{A. Latar Belakang}

Tujuan pembangunan kesehatan menuju Indonesia sehat 2025 adalah meningkatkan kesadaran. Kemauan, dan kemampuan hidup sehat bagi setiap orang agar peningkatan derajat kesehatan masyarakat yang setinggi-tingginya dapat terwujud melalui terciptanya masyarakat, bangsa dan negara Indonesia yang ditandai oleh penduduknya yang hidup dengan perilaku dan dalam lingkungan sehat, memiliki kemampuan untuk menjangkau pelayanan kesehatan yang setinggi-tingginya diseluruh wilayah Republik Indonesia (RPJK, 2005-2025,h.35).

Milenium Development Goals (MGDs), menerangkan delapan tujuan yang ditargetkan tercapai pada tahun 2015. Tujuan ke enam yaitu tentang menerangi HIV dan AIDS, malaria serta penyakit menular lainnya. Salah satu parameter dari penanganan penyakit menular adalah penyakit Demam Berdarah Dengue (DBD). Badan Kesehatan Dunia (WHO) memperingatkan negara-negara di dunia untuk bertindak mengatasi masalah
Demam Berdarah Dengue ( Stalker, 2008 ).

Demam Berdarah Dengue (DBD) merupakan salah satu penyakit yang disebabkan oleh virus dengue. Penyakit ini sangat berbahaya karena dapat menyebabkan penderita meninggal dalam waktu yang sangat pendek (beberapa hari). Vektor utama DBD adalah Aedes aegypti, sedangkan vektor potensialnya adalah Aedes albopictus.

Cara pencegahan/pemberantasan DBD yang dapat dilakukan saat ini ialah dengan memberantas vektor, karena vaksin untuk mencegah dan obat untuk membasmi virusnya belum tersedia. Cara yang dianggap paling tepat untuk memberantas vektor dikenal dengan istilah pemberantasan sarang nyamuk DBD (PSN DBD) dilakukan dengan cara biologi, kimia dan fisik (Profil Kesehatan Indonesia, 2012).

Pada tahun 2012, jumlah penderita DBD yang dilaporkan sebanyak 90.245 kasus dengan jumlah kematian 816 orang (Incidence Rate/Angka kesakitan $=37,11$ per 100.000 penduduk dan $\mathrm{CFR}=0,90 \%$ ). Terjadi peningkatan jumlah kasus pada tahun 2012 dibandingkan tahun 2011 yang 
sebesar 65.725 kasus dengan IR 27,67. Target Renstra angka kesakitan DBD tahun 2012 sebesar 53 per 100.000 penduduk, dengan demikian Indonesia telah mencapai target Renstra 2012. Berikut tren IR DBD selama kurun waktu 2007-2012.

Sejalan dengan peningkatan jumlah/angka kesakitan, jumlah kabupaten/kota terjangkit DBD pada tahun 2012 juga mengalami peningkatan, dari 374 $(75,25 \%)$ menjadi 417 Kabupaten/Kota $(83,9 \%)$ pada tahun 2012 . Peningkatan ini menunjukkan semakin luasnya penyebaran DBD. Berikut ini gambaran jumlah kabupaten/kota terjangkit tahun 2008-2012. Selama periode tahun 2005 sampai tahun 2012 jumlah kabupaten/kota terjangkit DBD cenderung meningkat (Profil Kesehatan Indonesia, 2012).

Kejadian DBD di Kabupaten Banyumas masih dapat ditemukan, berdasarkan data Dinas Kesehatan Kabupaten Banyumas dari tahun 2008-2012 masih ditemukan kasus DBD. Angka kejadian DBD tercatat 685 kasus pada tahun 2008, kemudian pada tahun 2009 terdapat 382 kasus dengan 5 orang meninggal. Kasus DBD mengalami peningkatan pada tahun 2010 yaitu 696 kasus dengan 7 orang meninggal. Tahun 2011 sebanyak 201 kasus dengan 3 orang meninggal dan pada tahun 2012 tercatat 200 kasus dengan 4 orang meninggal dan tahun 2013 tercatat 471 kasus sampai Bulan Desember (Laporan Dinas Kesehatan Kabupaten Banyumas Tahun 2013).

Wilayah Kecamatan di Kabupaten Banyumas dengan jumlah kasus DBD tertinggi tahun 2013 adalah Kecamatan Purwokerto Selatan yaitu sebanyak 76 kasus tercatat sampai bulan Desember tahun 2013. Berdasarkan data Puskesmas Purwokerto Selatan kasus DBD tahun 2009 - 2013 masih ditemukan. Kasus DBD tercatat pada tahun 2009 sebanyak 47 kasus, kemudian naik pada tahun 2010 sebanyak 126 kasus. Angka kejadian kasus mengalami penurunan pada tahun 2011 sebanyak 67 kasus, kemudian turun menjadi 31 kasus pada tahun 2012. Kasus DBD mengalami kenaikan pada tahun 2013 sampai Bulan Desember sebanyak 92 kasus. Desa yang paling tinggi kasus DBD adalah Kelurahan Karangpucung dengan kasus DBD sebanyak 21 kasus dengan ABJ 94,09 $\%$ dan Desa yang tertinggi kedua adalah Desa Teluk dengan kasus DBD sebanyak 20 kasus ABJ 96,68\%. Tindakan pengendalian vektor telah dilakukan termasuk PSN-DBD di Kecamatan Purwokerto Selatan, namun PSN-DBD belum maksimal dilakukan di Kelurahan Karangpucung sehingga $A B J$ belum mencapai 95,00 \% ( Puskesmas
Purwokerto Selatan, 2013 ).

Salah satu upaya untuk menurunkan tingkat kepadatan alami nyamuk Aedes sp tanpa insektisida yaitu menggunakan ovitrap. Ovitrap adalah alat pemancing atau perangkap nyamuk untuk bertelur di dalamnya (Tanjung, 2011). Ovitrap standar berupa tabung gelas kecil bermulut lebar yang dicat hitam di bagian luarnya. Tabung separuh diisi air hingga $3 / 4$ dan ditempatkan di lokasi yang diduga menjadi habitat nyamuk, biasanya di dalam atau di sekitar lingkungan rumah dengan melapisi bagian dalam tabung berupa kertas, sebagai tempat bertelur (Rakkang, 2013).

Keberhasilan penerapan metode perangkap telur nyamuk ini bergantung pada jumlah alat yang dipasang, lokasi pemasangan dan daya tariknya bagi nyamuk Aedes betina sebagai tempat bertelur. Untuk menarik penciuman nyamuk digunakan atraktan. Atraktan adalah sesuatu yang memiliki daya tarik terhadap serangga (nyamuk) baik secara kimiawi maupun visual (fisik). Aktraktan dari bahan kimia dapat berupa senyawa ammonia, $\mathrm{CO}$, asam laktat, octenol dan asam lemak. Zat atau senyawa tersebut berasal dari bahan organik atau merupakan hasil proses metabolisme makhluk hidup termasuk manusia. Atraktan fisika dapat berupa getaran atau suara dan warna, baik warna tempat atau cahaya. Atraktan dapat digunakan untuk mempengaruhi perilaku, memonitor atau menurunkan populasi nyamuk secara langsung tanpa menyebabkan cidera bagi binatang lain dan manusia dan tidak meninggalkan residu pada makanan atau bahan pangan.

Nyamuk Aedes aegypti dan Aedes albopictus biasanya memilih berkembang biak pada tandon air bersih, yang tidak bersentuhan dengan tanah. Selain itu nyamuk Aedes $s p$ dapat berkembang biak pada air rendaman udang. Air rendaman udang windu dapat digunakan sebagai atraktan yang paling menarik dari air hujan, dan air rendaman jerami karena air rendaman udang mengandung kadar $\mathrm{CO}_{2}$ dan Amonia yang tinggi sehingga dapat menarik penciuman dan mempengaruhi nyamuk dalam memilih tempat bertelur (Sayono, 2008 ).

Berdasarkan uraian tersebut, salah satu upaya untuk menurunkan tingkat kepadatan alami nyamuk Aedes sp yaitu menggunakan ovitrap, maka perlu dilakukan penelitian tentang Pengaruh modifikasi atraktan terhadap jumlah telur nyamuk Aedes $s p$ yang terperangkap di Kelurahan Karangpucung, Kecamatan Purwokerto Selatan, Kabupaten Banyumas tahun 2014 


\section{B. Rumusan Masalah}

Apakah ada pengaruh modifikasi atraktan terhadap jumlah telur Aedes $s p$ yang terperangkap di Kelurahan Karangpucung, Kecamatan Purwokerto Selatan, Kabupaten Banyumas Tahun 2014 ?

\section{Tujuan Penelitian}

1. Tujuan Umum

Mengetahui pengaruh modifikasi atraktan terhadap jumlah telur Aedes $s p$ yang terperangkap di Kelurahan Karangpucung, Kecamatan Purwokerto Selatan, Kabupaten Banyumas Tahun 2014.

2. Tujuan Khusus
a. Membandingkan jumlah telur nyamuk Aedes sp yang terperangkap pada ovitrap berdasarkan jenis atraktan.
b. Membandingjan jumlah telur nyamuk Aedes sp yang terperangkap pada pemasangan. ovitrap berdasarkan letak
c. Membandingkan jumlah telur nyamuk Aedes sp yang terperangkap pada ovitrap berdasarkan waktu pengamatan.

\section{Manfaat Penelitian}

1. Bagi Masyarakat Memberikan informasi dan pengetahuan sebagai alternatif atau cara yang sederhana dan murah untuk digunakan dalam pemantauan nyamuk Aedes sp.

2. Bagi Pemerintah

Hasil penelitian ini dapat menjadi tambahan informasi tentang metoda dan alat pemberantasan nyamuk Aedes sp, yang dapat direkomendasikan untuk diterapkan masyarakat. Memberikan perhatian bagi Dinas Kesehatan terhadap masalah vektor khususnya nyamuk Aedes $s p$ untuk mengurangi angka kematian akibat DBD serta menetapkan kebijakan khususnya dalam bidang pemantauan Aedes sp.

3. Bagi Almamater

Hasil penelitian ini dapat digunakan sebagai acuan peneliti sejenis dan serta tambahan bahan kepustakaan Poltekkes Kemenkes Semarang Jurusan Kesehatan Lingkungan Purwokerto.

4. Bagi Peneliti

Dapat menambah pengetahuan serta memberikan manfaat berupa pengaplikasian teknologi tepat guna sebagai salah satu upaya pemberantasan vektor nyamuk Aedes sp. Penelitian ini juga bermanfaat untuk menambah pengalaman serta memperoleh ilmu dari proses pembelajaran diluar kegiatan belajar di kampus.

\section{METODOLOGI PENELITIAN}

\section{A. Variabel Penelitian}

1. Jenis Varibel

a. Variabel bebas

Variabel bebas merupakan variabel yang menjadi sebab perubahan pada variabel terikat atau variabel yang mempengaruhi. Sebagai variabel bebas dalam penelitian ini adalah modifikasi atraktan.

b. Variabel terikat

Variabel terikat merupakan variabel yang dipengaruhi atau yang menjadi akibat adanya variabel bebas. Sebagai variabel terikat dalam penelitian ini adalah Jumlah telur nyamuk Aedes sp yang terperangkap di Kelurahan Karangpucung, Kecamatan Purwokerto Selatan, Kabupaten Banyumas.

c. Variabel pengganggu

Variabel pengganggu merupakan variabel yang mengganggu variabel bebas dan terikat. Variabel pengganggu dalam penelitian ini adalah pengasapan, abatisasi, penggunaan insektisida rumah tangga, dan PSN.

2. Strutur Hubungan Variabel

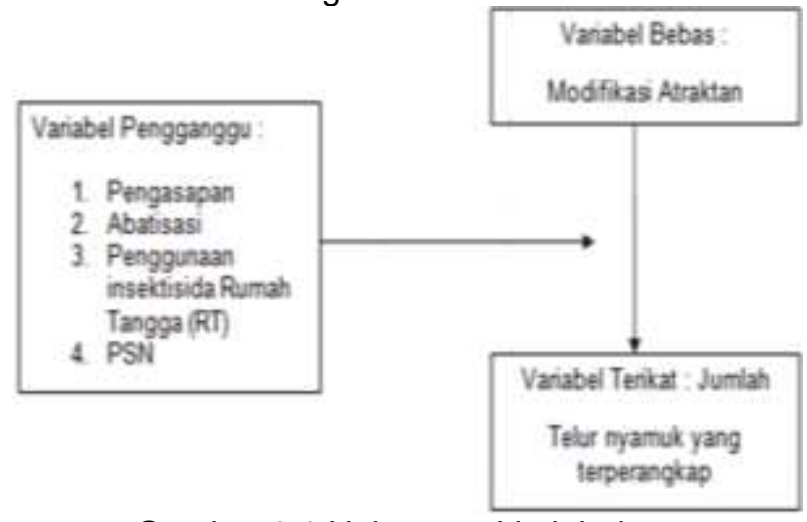

Gambar 2.1 Hubungan Variabe

\section{B. Jenis penelitian}

Penelitian ini menggunakan jenis penelitian Pra eksperimen, karena masih terdapat variabel luar yang ikut berpengaruh terhadap bentuknya variabel dependen. Rancangan penelitian ini menggunakan The static group comparison design (perbandingan kelompok statis) yaitu penelitian dengan cara ada kelompok perlakuan dan kelompok kontrol/ tidak diberi perlakuan (Djamaluddin, 2013, h.17).

Bentuk rancangan : $\mathrm{O}_{1} \mathrm{O}_{2} \mathrm{O}_{3} \quad \mathrm{X}_{\mathrm{O}_{4}} \mathrm{O}_{5}$ 
$\mathrm{O}_{6}$

\section{Ruang Lingkup}

Jenis penelitian inimenggunakan penelitian eksperimen. Ruang Lingkup dalam penelitian ini, peneliti menentukan ruang lingkup sebagai berikut :

1. Waktu

a. Tahap persiapan (September 2013 Februari 2014) meliputi:

1) Mencari bahan dan referensi

2) Mencari data dan subyek penelitian

3) Konsultasi judul proposal Karya Tulis IImiah

4) Penyusunan proposal Karya Tulis IImiah

5) Seminar proposal Karya Tulis IImiah

b. Tahap pelaksanaan (Maret 2014 Juni 2014)

1) Pengumpulan data

2) Pemasangan sampel

3) Perhitungan sampel

c. Tahap penyelesaian (Juni - Juli 2014)

1) Pengolahan data dan analisis data

2) Penulisan Karya Tulis IImiah

3) Ujian Karya Tulis IImiah

2. Lokasi

Lokasi penelitian ini yaitu di Kelurahan Karangpucung, Kecamatan Purwokerto Selatan, Kabupaten Banyumas.

3. Materi

Materi dalam penelitian ini adalah Pengendalian Vektor dan Binatang Pengganggu khususnya Pengendalian nyamuk Aedes $s p$ dengan menggunakan modifikasi atraktan.

\section{Populasi dan Sampel}

\section{Populasi}

Populasi adalah wilayah generalisasi yang terdiri atas objek/subjek yang mempunyai kuantitas dan karakteristik tertentu yang telah ditetapkan peneliti untuk kemudian dipelajari dan kemudian ditarik kesimpulannya (Setiawan, 2010). Populasi dalam penelitian ini adalah penderita DBD di Kelurahan Karangpucung, Kecamatan Purwokerto Selatan, Kabupaten Banyumas.

2. Sampel

Sampel merupakan bagian populasi yang akan diteliti atau sebagian jumlah dari karakteristik yang dimiliki oleh populasi (Hidayat, 2007). Sampel adalah objek yang diteliti dan dianggap mewakili seluruh populasi (Notoatmodjo, 2010). Penentuan sampel pada penelitian ini menggunakan kriteria inklusi yaitu:

a. Rumah penderita DBD pada tahun 2013 terbanyak berada di Rw 04
Kelurahan Karang Pucung yaitu sebanyak 5 penderita.

b. Terletak di Rt 02 Rw 04 sebanyak 1 rumah penderita, Rt 04 Rw 04 sebanyak 3 rumah dan Rt $05 \mathrm{Rw} 04$ sebanyak 1 rumah.

c. Tempat yang memiliki resiko menjadi breeding place dan resting nyamuk

\section{E. Pengumpulan Data} $\begin{array}{llr}\text { Teknik } & \text { pengumpulan } & \text { data } \\ \text { merupakan cara peneliti } & \text { untuk } \\ \text { mengumpulkan data yang akan } & \text { dilakukan } \\ \text { dalam penelitian (Hidayat, 2010). }\end{array}$

1. Jenis Data

a. Data Umum

Data umum meliputi keadaan geografis sekitar lingkungan Kelurahan Karangpucung, Kecamatan Purwokerto Selatan, Kabupaten Banyumas.

b. Data Khusus

Data khusus dalam penelitian ini adalah hasil eksperimen yang meliputi

1) Pengasapan pada lokasi penelitian

2) Abatisasi pada lokasi penelitian

3) Penggunaan Insektisida RT pada lokasi penelitian

4) PSN pada lokasi penelitian

5) Jumlah telur nyamuk Aedes $s p$ yang tertangkap dengan menggunakan atraktan air bersih, air rendaman udang rebon, dan air rendaman udang windu.

2. Sumber Data

a. Data Primer

Data primer adalah data yang diperoleh sendiri oleh penelitian dari hasil pengukuran, pengalaman dan survei (Arikunto,2005). Data primer dalam penelitian ini meliputi data yang diperoleh dari modifikasi atraktan jumlah telur nyamuk Aedes $s p$ yang tertangkap dengan air bersih, air rendaman udang rebon dan air rendaman udang windu.

b. Data Sekunder

Data sekunder adalah data yang diperoleh dari pihak lain, badan/instansi yang secara rutin mengumpulkan data (Arikunto,2006). Data sekunder diperoleh dari arsip Kelurahan Kecamatan Purwokerto Kabupaten Banyumas.

c. Cara Pengumpulan Data

Data dikumpulkan melalui observasi dan perhitungan secara langsung terhadap obyek yang diteliti. Observasi digunakan untuk mengetahui kegiatan pengasapan, abatisasi, penggunaan insektisida RT 
dan PSN di tempat penelitian, sedangkan menghitung digunakan untuk mengetahui banyaknya telur nyamuk Aedes sp yang tertangkap dengan modifikasi atraktan.

d. Instrumen Penelitian

Instrumentasi dalam penelitian ini yaitu kuesioner. Kuesioner / angket merupakan alat ukur berupa angket atau kuesioner dengan beberapa pertanyaan (Hidayat, 2007). Pengumpulan data diperoleh dengan wawancara responden rumah tempat penelitian. Kuesioner ini berisi tentang berbagai kegiatan Puskesmas pada kelurahan Karangpucung seperti melakukan pengasapan, abatisasi, penggunaan insektisida RT dan PSN.

\section{F. Analisis Data}

1. Analisis Univariat

Analisis univariat yang dilakukan terhadap tiap variabel dari penelitian. Pada analisis univariat, data yang diperoleh dari hasil pengumpulan dapat disajikan dalam bentuk tabel distribusi frekuensi, ukuran tendensi sentral atau grafik (Setiawan, 2009).
2. Analisis Bivariat

Data yang dikumpulkan diolah menggunakan analisis bivariat dengan menggunakan analysis of varians ( one way Anova ) yaitu untuk mengetahui pengaruh modifikasi ovitrap terhadap jumlah telur nyamuk Aedes sp yang terperangkap.

Tahap operasional rumus sebagai berikut :

a. Menghitung Faktor Koreksi (FK)

$F K=\frac{\left(\sum X i j^{2}\right)}{N} ;$ dimana $\mathrm{N}$ banyaknya data; $\left(\sum \mathrm{Xij}^{2}\right)$ jumlah data dikuadratkan

b. Jumlah Kuadrat Total (JKT)

$J K T=\sum X i j^{2}-F K ; \quad$ dimana $\sum \mathrm{Xij}^{2}$ jumlah nilai setelah dikuadratkan

c. Jumlah Kuadrat Perlakuan (JKP) $J K P=\sum \frac{\left(\sum X j^{2}\right)}{n_{i}} F K ; \quad$ dimana $\left(\sum \mathrm{Xj}\right)^{2}$ jumlah masing-masing kolom dikuadratkan $\mathrm{n}_{\mathrm{i}}$, banyaknya subyek pada kolom tersebut

d. Jumlah kuadrat sisa (JKS) $J K S=J K T-J K P$

e. Tabel Anova

Tabel ini digunakan untuk merekap hasil perhitungan guna memudahkan perhitungan selanjutnya.

Tabel 2.2 : Tabel Anova

\begin{tabular}{|l|l|l|l|l|l|}
\hline $\begin{array}{c}\text { Sumber } \\
\text { variasi }\end{array}$ & \multicolumn{1}{|c|}{ Df } & $\begin{array}{c}\text { Jumlah } \\
\text { Kuadrat }\end{array}$ & Kuadrat Tengah & $\boldsymbol{F}_{\text {hitung }}$ & $\begin{array}{c}\text { Fa; dfp; } \\
\text { dfs }\end{array}$ \\
\hline Perlakuan & $D f_{p}=j-1$ & JKP & $K T P=\frac{J K P}{D f_{S}}$ & $\frac{K T P}{K T S}$ & Lihat Tabel \\
\hline Sisa & $D f_{s}=(n-1)-(j-1)$ & JKS & $K T S=\frac{J K S}{D f_{S}}$ & & \\
\hline Total & $D f_{1}=N-1$ & & & & \\
\hline
\end{tabular}

Jika Ho ditolak maka di lanjut Anova yaitu LSD (Least Segnificance Difference atau beda nyata terkecil) ( Aris, 2008 ).

\section{HASIL}

\section{A. Gambaran Umum}

1. Keadaan Geografi

Kelurahan karangpucung merupakan salah satu wilayah di Kecamatan Purwokerto Selatan yang memiliki 12 RW dan 57 RT. Luas wilayah Kelurahan Karangpucung yaitu 856.000 $\mathrm{Ha}$, yaitu meliputi daerah persawahan, tanah kering, tanah perkebunan dan fasilitas umum.

Wilayah Karangpucung memiliki batas wilayah sebagai berikut:
a. Sebelah Timur
: Kelurahan
b. Sebelah Barat
Purwokerto Kulon
: Kelurahan
Tanjung

c. Sebelah Utara : Kelurahan Kranji

d. Sebelah Selatan :Kelurahan

Karangklesem

2. Keadaan Demografi

a. Pertumbuhan Penduduk

Berdasarkan data dari buku profil Kesehatan Puskesmas Purwokerto Selatan, wilayah Kelurahan Karangpucung memiliki penduduk yaitu 13.318 jiwa terdiri dari laki-laki 6.787 atau $50,96 \%$ dan perempuan 6.531 atau 49,03\% dengan jumlah Kepala Keluarga sebanyak 3756 KK.

b. Jumlah Penduduk Menurut Kelompok Umur

Jumlah penduduk kelompok umur dan jenis kelamin di Kelurahan Karangpucung, dapat dilihat pada tabel sebagai berikut : 
Tabel 3.1 : Data Penduduk Menurut Kelompok Umur Di Wilayah Karangpucung Tahun 2014

\begin{tabular}{cccc}
\hline No & $\begin{array}{c}\text { KelompokUmur } \\
\text { (fanun) }\end{array}$ & $\begin{array}{c}\text { Jumian Penduduk } \\
\text { (Orana) }\end{array}$ & \% Penduduk \\
\hline 1 & $0-4$ & 897 & 6.72 \\
\hline 2 & $5-9$ & 1.087 & 8.15 \\
\hline 3 & $10-14$ & 1.073 & 8.04 \\
\hline 4 & $15-19$ & 969 & 7.26 \\
\hline 5 & $20-24$ & 1.028 & 7.71 \\
\hline 6 & $25-29$ & 1.175 & 8.81 \\
\hline 7 & $30-34$ & 1.364 & 10.23 \\
\hline 8 & $35-39$ & 1.142 & 8.56 \\
\hline 9 & $40-44$ & 960 & 7.20 \\
\hline 10 & $45-49$ & 861 & 6.45 \\
\hline 11 & $50-54$ & 760 & 5.70 \\
\hline 12 & $55-59$ & 674 & 5.05 \\
\hline 13 & $60-64$ & 493 & 3.69 \\
\hline 14 & $65-69$ & 287 & 2.15 \\
\hline 15 & $70-74$ & 234 & 1.75 \\
\hline 16 & $75-79$ & 162 & 1.21 \\
\hline 17 & $80-84$ & 90 & 0.67 \\
\hline 18 & $85-89$ & 51 & 0.38 \\
\hline 19 & $90-94$ & 11 & 0.08 \\
\hline 20 & 95 keatas & 12 & 0.09 \\
\hline & Jumlah & 13.330 & 100 \\
\hline
\end{tabular}

Sumber : Profil Kelurahan Karangpucung Tahun 2014

\section{Keadaan Topografi}

Wilayah Kelurahan Karangpucung terletak pada ketinggian 74 meter dari permukaan laut, dengan curah hujan 99 $\mathrm{mm} /$ tahun.

4. Keadaan Sosial Ekonomi

a. Tingkat Ekonomi

Data pendidikan penduduk di Wilayah Kelurahan Karangpucung adalah sebagai berikut:

Tabel 3.2 : Data Penduduk Menurut Jenjang Pendidikan di Wilayah Kelurahan Karangpucung Tahun 2014

\begin{tabular}{|l|c|c|}
\hline $\begin{array}{c}\text { Jenjang } \\
\text { Pendidikan }\end{array}$ & $\begin{array}{c}\text { Jumlah Penduduk } \\
\text { (Orang) }\end{array}$ & $\begin{array}{c}\% \\
\text { Penduduk }\end{array}$ \\
\hline Belum Sekolah & 2.215 & 16,63 \\
\hline Tidak Tamat & 1.408 & 7,86 \\
\hline SD/Sederajat & 2.731 & 20,50 \\
\hline SLTP/Sederajat & 1.913 & 14,36 \\
\hline SLTA/Sederajat & 3.589 & 26,94 \\
\hline D-1/D-2 & 84 & 0,63 \\
\hline D-3 & 332 & 2,49 \\
\hline S-1 & 969 & 7,27 \\
\hline S-2 & 77 & 0,57 \\
\hline Jumlah & 13.318 & 100 \\
\hline
\end{tabular}

Sumber : Profil Kelurahan Karangpucung Tahun 2014 b. Mata Pencaharian Penduduk

Tabel 3.3 :Data Penduduk Menurut Mata Pencaharian di Wilayah

Kelurahan Karangpucung

Tahun 2014

\begin{tabular}{|c|c|c|c|}
\hline No & $\begin{array}{c}\text { Jenjang } \\
\text { Pendidikan }\end{array}$ & $\begin{array}{l}\text { Jumlah } \\
\text { Penduduk } \\
\text { (Orang) }\end{array}$ & $\begin{array}{c}\% \\
\text { Penduduk }\end{array}$ \\
\hline 1. & Apoteker & 5 & $0,03 \%$ \\
\hline 2. & Bidan & 6 & $0,04 \%$ \\
\hline 3. & Buruh Harian Lepas & 1.196 & $8,9 \%$ \\
\hline 4. & Buruh Ternak & 1 & $0,007 \%$ \\
\hline 5. & Buruh Tani & 1 & $0,007 \%$ \\
\hline 6. & Dokter & 10 & $0,07 \%$ \\
\hline 7. & Dosen & 12 & $0,09 \%$ \\
\hline 8. & Guru & 115 & $0,8 \%$ \\
\hline 9. & Industri & 3 & $0,02 \%$ \\
\hline 10. & BUMD & 9 & $0,06 \%$ \\
\hline 11. & BUMN & 77 & $0,5 \%$ \\
\hline 12. & Karyawan Honorer & 45 & $0,3 \%$ \\
\hline 13. & Karyawan Swasta & 1.965 & $14,7 \%$ \\
\hline 14. & Konsultan & 2 & $0,01 \%$ \\
\hline 15. & Konstruksi & 11 & $0,08 \%$ \\
\hline 16. & Mekanik & 15 & $0,11 \%$ \\
\hline 17. & Notaris & 1 & $0,007 \%$ \\
\hline 18. & Pastur & 1 & $0,007 \%$ \\
\hline 19. & Pedagang & 256 & $1,9 \%$ \\
\hline 20. & Pegawai Negeri Sipil & 241 & $1,8 \%$ \\
\hline 21. & Pelaut & 1 & $0,007 \%$ \\
\hline 22. & $\begin{array}{l}\text { Pembantu Rumah } \\
\text { Tangga }\end{array}$ & 36 & $0,2 \%$ \\
\hline 23. & Penata Busana & 1 & $0,007 \%$ \\
\hline 24. & Penata Rambut & 5 & $0,03 \%$ \\
\hline 25. & POLRI & 22 & $0,16 \%$ \\
\hline 26. & Pendeta & 2 & $0,01 \%$ \\
\hline 27. & Pengacara & 1 & $0,007 \%$ \\
\hline 28. & Pensiun & 303 & $2,27 \%$ \\
\hline 29. & Perangkat Desa & 2 & $0,01 \%$ \\
\hline 30. & Perdagangan & 66 & $0,49 \%$ \\
\hline 31. & Petani/ Perkebun & 50 & $0,37 \%$ \\
\hline 32. & Peternak & 2 & $0,01 \%$ \\
\hline 33. & Promotor Acara & 1 & $0,007 \%$ \\
\hline 34. & Physikiater & 1 & $0,007 \%$ \\
\hline 35. & Seniman & 1 & $0,007 \%$ \\
\hline 36. & Sopir & 73 & $0,5 \%$ \\
\hline 37. & Tabib & 1 & $0,007 \%$ \\
\hline 38. & TNI & 18 & $0,13 \%$ \\
\hline 39. & Transportasi & 33 & $0,24 \%$ \\
\hline 40. & Tukang Batu & 35 & $0,24 \%$ \\
\hline 41. & Tukang Cukur & 1 & $0,007 \%$ \\
\hline 42. & Tukang Jahit & 43 & $0,32 \%$ \\
\hline 43. & Tukang Kayu & 72 & $0,54 \%$ \\
\hline 44. & Tukang Las & 4 & $0,03 \%$ \\
\hline 45. & Ustad & 1 & $0,007 \%$ \\
\hline 46. & Wartawan & 1 & $0,007 \%$ \\
\hline 47. & Wiraswasta & 747 & $5,6 \%$ \\
\hline 48. & Perawat & 12 & $0,09 \%$ \\
\hline 49. & $\begin{array}{ll}\text { Mengurus } & \text { Rumah } \\
\text { Tangga } & \end{array}$ & 2.337 & $17,54 \%$ \\
\hline 50. & Pelajar/ Mahasiswa & 2.418 & $18.15 \%$ \\
\hline 51. & Belum kerja & 2.662 & $19,98 \%$ \\
\hline
\end{tabular}

Sumber : Profil Kelurahan Karangpucung Tahun 2014 


\section{B. Gambaran Khusus}

Pemasangan ovitrap di Kelurahan Karangpucung dilakukan pada wilayah yang memiliki kasus terbanyak yaitu di Rw 04 dengan jumlah rumah reponden sebanyak 5 rumah, terletak di Rt 02 Rw 04 sebanyak 1 rumah responden, Rt $04 \mathrm{Rw} 04$ sebanyak 3 rumah responden dan Rt 05 Rw 04 sebanyak 1 rumah responden. Lokasi rumah responden tersebut dekat dengan jalan raya dan ada yang saling berdekatan sehingga mempercepat penyebaran penyakit DBD.

Pemasangan ovitrap pada setiap rumah dipasang 6 ovitrap yaitu 3 pemasangan di luar rumah dan 3 pemasangan di dalam rumah reponden. Ovitrap berisi atraktan 3 jenis yaitu air bersih, air rendaman udang windu, dan air rendaman udang rebon. Masing-masing ovitrap diberi atraktan dan dilapisi pada bagian dalam tabung berupa kertas (ovistrip), sebagai tempat bertelur dengan ujung kertas sedikit mengenai permukaan air. Setiap harinya dilakukan pengamatan untuk mengamati ada tidaknya telur yang terperangkap, apabila ditemukan telur maka kertas diambil dan diganti dengan yang baru. Kertas yang ditemukan telur tadi kemudian dimusnahkan dengan cara dibakar untuk menghindari perkembang biakan nyamuk.

Letak pemasangan ovitrap di luar rumah berada di sekitar halaman rumah yaitu pada teras depan rumah, dekat semak-semak, dekat tumpukan barang bekas, dibawah kursi yang kondisinya gelap dan lembab, sedangkan di dalam rumah terletak pada gudang, dibawah tempat duduk, dan dekat barang-barang bekas.

\section{Hasil Penelitian}

Secara umum, jumlah telur nyamuk Aedes $s p$ yang terperangkap selama satu minggu dengan 7 kali pengamatan mencapai 1.370 butir, dengan rata-rata 195,7 butir per ovitrap. Namun demikian, tidak semua ovitrap terdapat telur nyamuk Aedes $s p$ terperangkap. Jumlah telur nyamuk yang terperangkap dapat dibedakan berdasarkan jenis atraktan, letak pemasangan, dan waktu pengamatan.

Berdasarkan hasil penelitian yang telah dilakukan pengaruh modifikasi ovitrap terhadap jumlah telur nyamuk Aedes $s p$ yang terperangkap di Kelurahan Karangpucung, Kecamatan Purwokerto Selatan, Kabupaten Banyumas adalah sebagai berikut :

Tabel 3.4 :Jumlah Telur Nyamuk Aedes sp yang Terperangkap pada Modifikasi Atraktan di Kelurahan Karangpucung Kecamatan Purwokerto Selatan Kabupaten Banyumas Tahun 2014

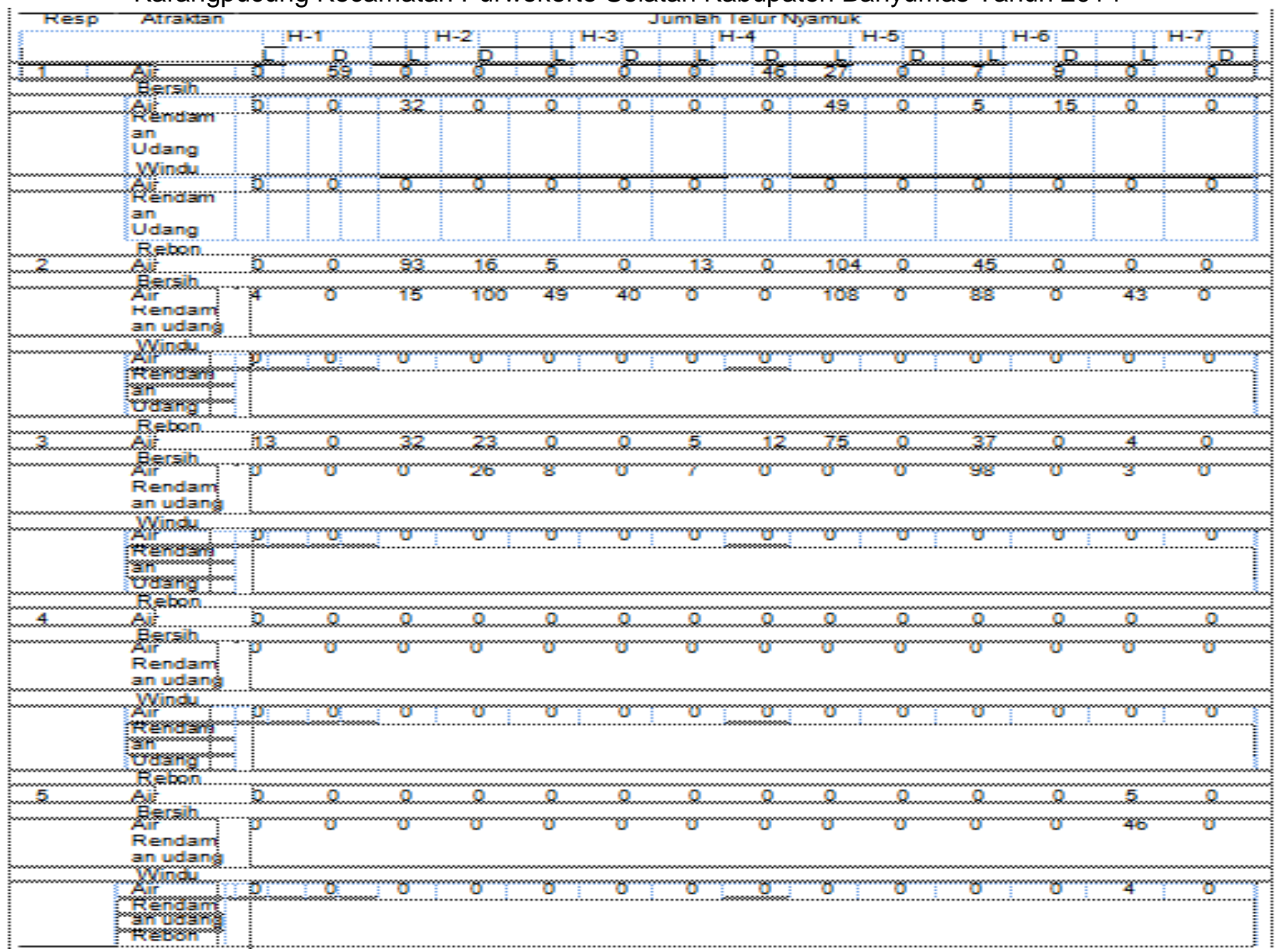


1. Jumlah Telur Nyamuk Aedes $s p$ yang Terperangkap Berdasarkan Jenis Atraktan

Tabel 3.5 : Jumlah Telur Nyamuk Aedes sp yang Terperangkap pada Atraktan Air Bersih

\begin{tabular}{|c|c|c|}
\hline Responden & LO & $\begin{array}{c}\text { } \\
\text { yang Telur Nyamuk } \\
\text { pada Air Bersih }\end{array}$ \\
\hline 1 & L & 34 \\
\hline & D & 114 \\
\hline 2 & L & 260 \\
\hline & D & 16 \\
\hline 3 & L & 166 \\
\hline & D & 35 \\
\hline 4 & L & 0 \\
\hline & D & 0 \\
\hline 5 & L & 5 \\
\hline & D & 0 \\
\hline \multicolumn{2}{|c|}{ Total } & 630 \\
\hline
\end{tabular}

Tabel di atas menunjukkan jumlah keseluruhan telur nyamuk yang terperangkap pada ovitrap dengan atraktan air bersih mengalami fluktuasi, jumlah telur nyamuk ditemukan tinggi pada ovitrap rumah responden kedua yaitu sebanyak 260 butir pada peletakkan pemasangan ovitrap di luar rumah sedangkan pengamatan pada atraktan air bersih di rumah responden keempat letak pemasangan baik di luar maupun di dalam rumah tidak ditemukan telur nyamuk yang terperangkap.

Tabel 3.6 : Jumlah Telur Nyamuk Aedes sp yang Terperangkap pada Atraktan Air Rendaman Udang Windu

\begin{tabular}{|c|c|c|}
\hline Responden & LO & $\begin{array}{c}\text { Telur Nyamuk } \\
\text { yang Terperangkap } \\
\text { pada Air Rendaman } \\
\text { Udang Windu }\end{array}$ \\
\hline 1 & L & 54 \\
\hline & D & 47 \\
\hline 2 & L & 307 \\
\hline & D & 140 \\
\hline 3 & L & 116 \\
\hline & D & 26 \\
\hline 4 & L & 0 \\
\hline & D & 0 \\
\hline 5 & L & 46 \\
\hline & D & 0 \\
\hline Total & & 736 \\
\hline
\end{tabular}

Tabel di atas menunjukkan bahwa jumlah total telur nyamuk Aedes $s p$ yang terperangkap pada air rendaman udang windu dalam pengamatan selama 7 hari di 5 rumah responden adalah 736 butir. Jumlah telur nyamuk yang terperangkap pada air rendaman udang windu paling banyak terdapat di rumah responden kedua.

Tabel 3.7: Jumlah Telur Nyamuk Aedes sp yang Terperangkap pada Atraktan Air Rendaman Udang Rebon

\begin{tabular}{|c|c|c|}
\hline Responden & LO & $\begin{array}{c}\sum \text { Telur Nyamuk } \\
\text { yang Terperangkap } \\
\text { pada Air Rendaman } \\
\text { Udang Rebon }\end{array}$ \\
\hline \multirow[t]{2}{*}{1} & $\mathrm{~L}$ & 0 \\
\hline & $\mathrm{D}$ & 0 \\
\hline \multirow[t]{2}{*}{2} & $\mathrm{~L}$ & 0 \\
\hline & $\mathrm{D}$ & 0 \\
\hline \multirow[t]{2}{*}{3} & $L$ & 0 \\
\hline & D & 0 \\
\hline \multirow[t]{2}{*}{4} & $L$ & 0 \\
\hline & $\mathrm{D}$ & 0 \\
\hline \multirow[t]{2}{*}{5} & $\mathrm{~L}$ & 4 \\
\hline & $\mathrm{D}$ & 0 \\
\hline \multicolumn{2}{|l|}{ Total } & 4 \\
\hline
\end{tabular}

Tabel di atas menunjukkan bahwa jumlah telur nyamuk yang terperangkap pada atraktan air rendaman udang rebon terdapat di lokasi pemasangan ovitrap rumah responden kelima yaitu sebanyak 4 butir telur nyamuk, sedangkan pada lokasi responden lain nyamuk tidak tertarik meletakkan telurnya pada air rendaman udang rebon.

Tabel 3.8 :Perbandingan Jumlah Telur Nyamuk Aedes $s p$ terhadap Modifikasi Atraktan di Kelurahan Karangpucung Kecamatan Purwokerto Selatan Kabupaten Banyumas Tahun 2014

\begin{tabular}{|l|l|c|}
\hline No & Jenis Atraktan & $\begin{array}{c}\text { Jumlah Telur } \\
\text { Nyamuk } \\
\text { Terperangkap } \\
\text { (Butir) }\end{array}$ \\
\hline 1. & Air Bersih & 630 \\
\hline 2. & $\begin{array}{l}\text { Air Rendaman } \\
\text { Udang Windu }\end{array}$ & 736 \\
\hline 3. & $\begin{array}{l}\text { Air Rendaman } \\
\text { Udang Rebon }\end{array}$ & 4 \\
\hline
\end{tabular}

Tabel di atas menunjukkan bahwa modifikasi atraktan sebagai perangkap telur nyamuk Aedes sp dengan berbagai jenis atraktan seperti air bersih, air rendaman udang windu, air rendaman udang rebon didapatkan hasil pengamatan atraktan yang dapat menjadi perangkap telur nyamuk tertinggi adalah air rendaman udang windu dengan total jumlah telur yang terperangkap sebanyak 736 butir. 
2. Jumlah telur Nyamuk Aedes $s p$ yang terperangkap berdasarkan letak pemasangan

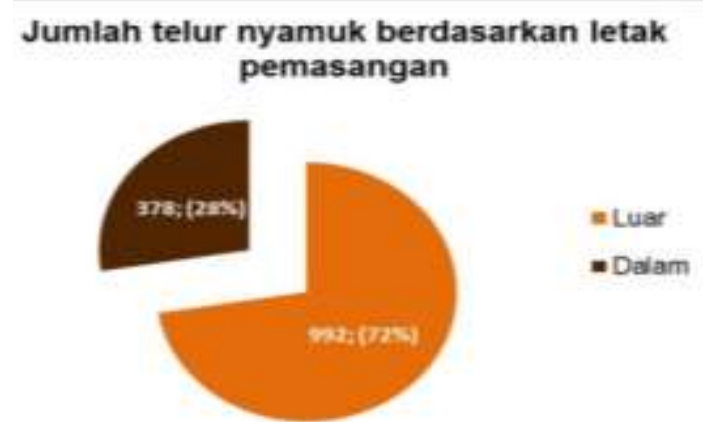

Grafik 3.1 Jumlah Telur Nyamuk Aedes sp yang Terperangkap berdasarkan letak pemasangan ovitrap di Kelurahan karangpucung Kecamatan Purwokerto Selatan Kabupaten Banyumas Tahun 2014

Grafik 3.1 menunjukkan prosentase jumlah telur nyamuk yang terperangkap berdasarkan letak pemasangan ovitrap di luar rumah dan di dalam rumah responden adalah ovitrap yang dipasang di luar rumah hasilnya lebih banyak yaitu 992 butir dengan prosentase $72 \%$ dibandingkan dengan ovitrap yang dipasang di dalam rumah yaitu sebanyak 378 butir dengan prosentase sebesar $28 \%$ dari jumlah telur keseluruhan sebanyak 1.370 butir.

3. Jumlah telur nyamuk Aedes sp yang terperangkap berdasarkan waktu pengamatan

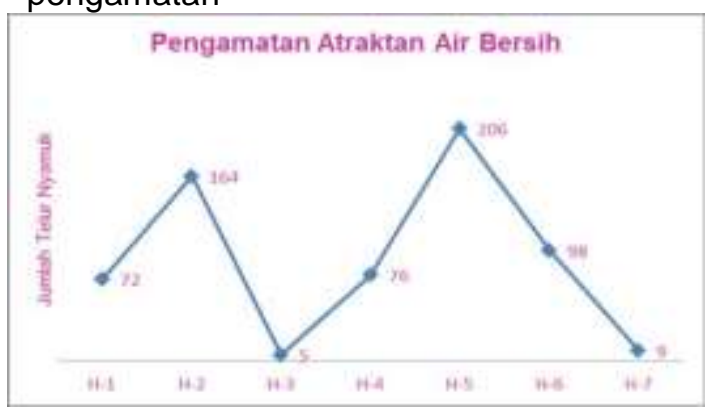

Grafik 3.2 Jumlah Telur Nyamuk Aedes $s p$ pada Atraktan Air Bersih selama

Pengamatan di Kelurahan

Karangpucung Kecamatan Purwokerto

Selatan Kabupaten Banyumas Tahun 2014

Grafik 3.2 menunjukkan bahwa pemasangan ovitrap dilihat dari waktu pengamatan, jumlah telur nyamuk yang terperangkap dalam atraktan air bersih mengalami fluktuasi. Waktu pengamatan jumlah telur nyamuk tertinggi pada hari kelima pemasangan dengan jumlah telur nyamuk 206 butir dan turun pada hari ketiga serta ketujuh pemasangan.
Pengamatan Atraktan Air Rendaman Udang Windu

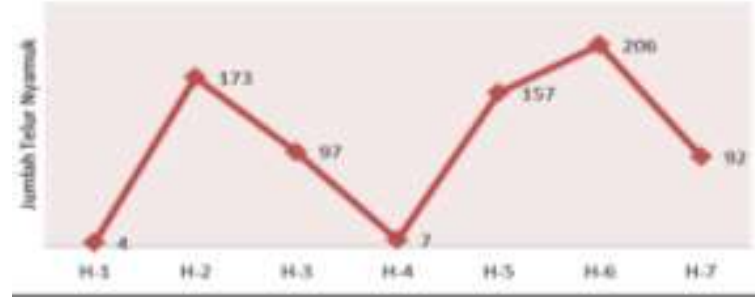

Grafik 3.3 Jumlah Telur Nyamuk Aedes $s p$ pada Atraktan Air Rendaman Udang Windu selama Pengamatan di

Kelurahan Karangpucung Kecamatan Purwokerto Selatan Kabupaten Banyumas Tahun 2014

Grafik di atas menunjukkan jumlah telur nyamuk Aedes sp yang berisi atraktan air rendaman udang windu yang terperangkap selama waktu pemasangan mengalami fluktuasi. Waktu tertinggi telur nyamuk terperangkap yaitu pada hari keenam sebanyak 206 butir dan paling rendah pada saat pemasangan hari pertama dengan jumlah 4 butir.

\section{Pengamatan Atraktan Air Rendaman} Udang Rebon

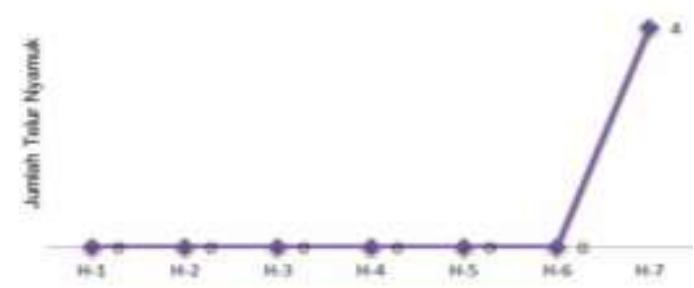

Grafik 3.4 Jumlah Telur Nyamuk Aedes sp pada Atraktan Air rendaman Udang Rebon selama Pengamatan di Kelurahan

Karangpucung Kecamatan Purwokerto Selatan Kabupaten Banyumas Tahun 2014

Grafik 3.4 menunjukkan hasil penelitian pemasangan ovitrap bahwa jumlah telur nyamuk Aedes $s p$ yang terperangkap pada atraktan air rendaman udang rebon hari pertama sampai hari keenam tidak ada telur nyamuk yang terperangkap, sedangkan pada hari ketujuh jumlah telur nyamuk yang terperangkap mengalami kenaikan sebanyak 4 butir. 
4. Faktor Yang Mempengaruhi

a. Pengasapan

Penggunaan Pengasapan

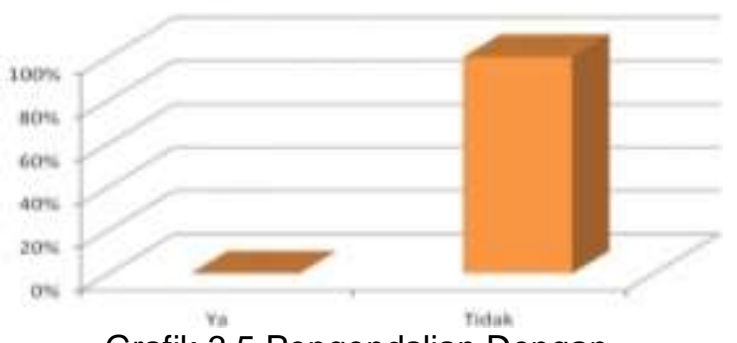

Grafik 3.5 Pengendalian Dengan

Pengasapan Di Kelurahan Karangpucung Kecamatan Purwokerto Selatan Kabupaten

Banyumas Tahun 2014

Grafik di atas menunjukkan prosentase wawancara reponden tentang pengendalian nyamuk Aedes $s p$ dengan pengasapan di Kelurahan Karangpucung Kecamatan Purwokerto Selatan Kabupaten Banyumas adalah $100 \%$ tidak adanya pengendalian dengan pengasapan saat penelitian dilaksanakan.

b. Abatisasi

\section{Penggunaan Abatisasi}

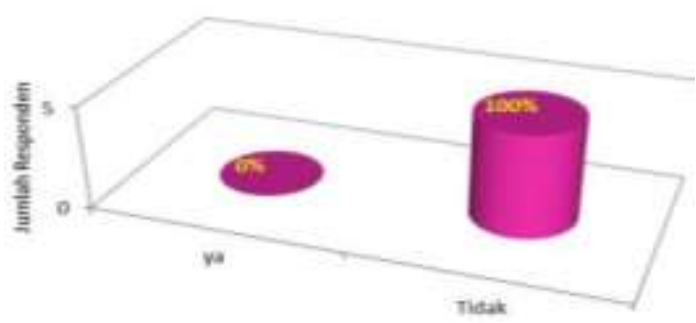

Grafik 3.6 Pengendalian dengan

Penggunaan Abatisasi di Kelurahan Karangpucung Kecamatan Purwokerto Selatan Kabupaten Banyumas tahun 2014

Grafik di atas menunjukkan bahwa responden di Kelurahan Karangpucung $\quad 100 \%$ tidak menggunakan teknik abatisasi untuk pengendalian larva nyamuk. Sehingga dapat dipastikan kepedulian masyarakat tersebut sangat kurang untuk pengendalian penyakit demam berdarah. c. Penggunaan Insektisida Rumah Tangga

Penggunaan Insektisida Rumah Tangga

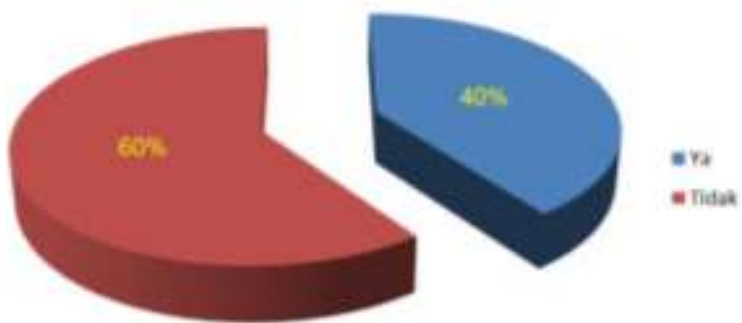

Gambar 3.7 Pengendalian Dengan Penggunaan Insektisida Rumah Tangga Di Kelurahan Karangpucung Kecamatan Purwokerto Selatan Kabupaten Banyumas tahun 2014

Gambar 3.7 menunjukkan bahwa faktor lain yang mempengaruhi jumlah telur nyamuk yang terperangkap pada ovitrap salah satunya dengan penggunaan insektisida rumah tangga atau lebih sering dikenal dengan obat anti nyamuk. Penggunaan insektisida rumah tangga di Kelurahan Karangpucung, Purwokerto Selatan ini dari kelima responden dengan prosentase sebesar $60 \%$ tidak menggunakan insektisida rumah tangga dan sisanya $40 \%$ menggunakan insektisida rumah tangga. Insektisida rumah tangga tersebut yang digunakan berupa obat nyamuk bakar dan semprot.

d. Pemberantasan Sarang Nyamuk (PSN)

\section{Pemberantasan Sarang Nyamuk}

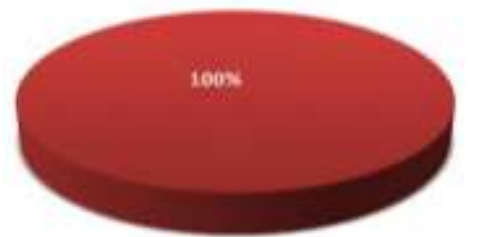

Gambar 3.8 Pemberantasan Sarang Nyamuk (PSN) di kelurahan

Karangpucung Kecamatan Purwokerto Selatan Kabupaten Banyumas Tahun 2014 
Gambar 3.8 menunjukan bahwa kepedulian masyarakat Kelurahan Karangpucung pada kelima responden dalam pemberantasan sarang nyamuk dengan kegiatan $3 \mathrm{M}$ ( Menguras bak penampungan air, menutup tempat penampungan air, dan mengubur barang bekas) $100 \%$ mereka tidak melaksanakannya dengan baik. Terlihat dari banyaknya barangbarang bekas yang dapat menampung air hujan berserakan di sekitar rumah responden. Hal tersebut dapat menjadi breeding dan potensial breeding place bagi nyamuk Aedes sp.

5. Hasil Uji Statistika

Tabel 3.9: Hasil uji statistika jumlah telur

nyamuk Aedes sp yang Terperangkap pada Ovitrap di Kelurahan Karangpucung kecamatan Purwokerto Selatan Kabupaten Banyumas Tahun 2014

\begin{tabular}{lr}
\hline & \multicolumn{2}{c}{$\begin{array}{c}\text { Jumlah Telur Nyamuk } \\
\text { yang Terperangkap }\end{array}$} \\
\hline Chi-Square & 10.049 \\
\hline df & 2 \\
\hline Asymp. Sig. & .007 \\
\hline
\end{tabular}

Tabel 3.9 menunjukkan hasil yang diperoleh dari uji statistika menggunakan Kruskal Wallis secara signifikan $\mathrm{p}=0,007 \leq a \quad 0,05$, artinya ada perbedaan secara signifikan antara jumlah telur nyamuk Aedes $s p$ yang terperangkap pada masing-masing atraktan.

\section{PEMBAHASAN}

\section{A. Gambaran Umum}

1. Keadaan Geografi

$\mathrm{S}$ e c a r a administratif Kelurahan Karangpucung termasuk dalam wilayah Kecamatan Purwokerto Selatan. Secara kewilayahan Kelurahan Karangpucung terdiri dari 12 RW 57 RT. Kondisi tersebut dapat mempengaruhi distribusi maupun kepadatan nyamuk Aedes $s p$ di Kecamatan Purwokerto Selatan. Hal ini dimungkinkan karena antara wilayah yang ada masih memungkinkan bagi nyamuk untuk berpindah.

Upaya pencegahan terhadap nyamuk Aedes $s p$ agar tidak menyebar ke wilayah lain yang berbatasan langsung, maka perlu adanya koordinasi maupun kerja sama yang baik dari semua pihak yang berwenang untuk memperlancar pelaksanaan operasional di lapangan dan yang paling penting adalah pemberantasan sarang nyamuk di Kecamatan Purwokerto Selatan.

Keadaan iklim di Indonesia umumnya sangat cocok untuk pertumbuhan maupun perkembangan nyamuk Aedes $s p$. Suhu udara yang disenangi nyamuk tersebut dalam siklus hidupnya mulai dari telur, larva, kepompong, sampai dewasa adalah antara $25^{\circ} \mathrm{C}-27^{\circ} \mathrm{C}$ (Depkes RI, 2007) Sedangkan suhu udara di Kelurahan Karangpucung yaitu berkisar $27^{\circ} \mathrm{C}-30^{\circ} \mathrm{C}$, sehingga memungkinkan berpotensi untuk tempat hidup nyamuk maupun larva.

2. Keadaan Topografi

Nyamuk Aedes $s p$ dapat tumbuh dan berkembang pada daerah yang memiliki ketinggian kurang dari 1000 meter dari permukaan laut, sedangkan Kelurahan Karangpucung terletak pada ketinggian 74 meter dari permukaan laut. Kondisi ini sangat memungkinkan untuk berkembangnya nyamuk Aedes $s p$ karena jika ketinggian lebih dari 1000 meter suhu udara terlalu rendah, sehingga tidak memungkinkan bagi kehidupan nyamuk tersebut. Selain itu curah hujan yang lebat menyebabkan bersihnya tempat perkembangbiakan vektor karena jentiknya hanyut dan mati. Kejadian penyakit yang ditularkan nyamuk biasanya meninggi beberapa waktu sebelum musim hujan lebat. Terlalu banyak hujan akan mengakibatkan kekeringan, mengakibatkan berpindahnya tempat perkembangbiakan vektor akan berkurang. Curah hujan yang cukup dengam jangka waktu lama akan memperbesar kesempatan nyamuk berkembang biak secara optimal. DIT.JEN.PP \& PL, 2007,h.7).

3. Keadaan demografi Jumlah penduduk kelurahan Karangpucung Kecamatan Purwokerto Selatan Kabupaten Banyumas yaitu 13.318 jiwa terdiri dari laki-laki 6.787 atau $50,96 \%$ dan perempuan 6.531 atau 49,03\% dengan jumlah Kepala Keluarga sebanyak $3756 \mathrm{KK}$. Luas wilayah Kelurahan Karangpucung yaitu 856.000 $\mathrm{Ha}$, yaitu meliputi daerah persawahan, tanah kering, tanah perkebunan dan fasilitas umum. Melihat luas wilayah Kelurahan Karangpucung termasuk dalam kategori desa kecil karena memiliki luas kurang lebih $8,56 \mathrm{~km}^{2}$ dan jumlah penduduk sebanyak 13.318 jiwa. Hal ini dapat dikatakan bahwa Kelurahan Karangpucung masuk dalam 
kategori desa padat penduduk.
Kepadatan mempengaruhi banyaknya kasus DBD. Kebiasaan masyarakat pada umumnya membuang barang-barang bekas di sembarang tempat, misalnya di pekarangan rumah, dibiarkan dalam rumah pada pojok-pojok dinding rumah.

\section{B. Gambaran Khusus}

Kondisi lingkungan fisik rumah responden sebagian besar terdapat barang bekas dengan genangan air, tempat gelap dan dipengaruhi oleh musim sangat cocok untuk berkembang biak nyamuk.

Kondisi lingkungan fisik pada rumah responden 1 letak pemasangan ovitrap berposisi di depan teras dekat dengan dinding dan berada di gudang penyimpanan barang bekas dengan kondisi gelap dan lembab. Kondisi lingkungan fisik rumah responden 2 letak pemasangan berada dekat dengan semak-semak samping rumah dan diletakkan di tempat yang gelap dibawah tempat duduk. Kondisi lingkungan fisik rumah responden 3 letak pemasangan berada disamping dinding rumah dan berada dekat dengan barang-barang bekas dengan kondisi ruangan yang gelap dan lembab. Kondisi lingkungan fisik rumah responden 4 letak pemasangan ovitrap berada dekat dengan tempat duduk yang jarang terpakai dengan kondisi lembab dan berada dekat dengan barang-barang yang tidak terpakai. Kemudian kondisi lingkungan fisik rumah responden 5 letak pemasangan ovitrap di luar rumah berada dekat semak-semak, barang-barang bekas yang tidak terpakai, dan dekat dengan penyimpanan barang yang tidak terpakai, dekat pipa saluran air bersih serta tempat cucian kotor.

Kondisi - kondisi tersebut sebagai breeding place dan resting place bagi nyamuk Aedes sp. Tempat yang disenangi nyamuk untuk hinggap istirahat selama menunggu waktu bertelur adalah tempattempat yang gelap, lembab, dan sedikit angin (Ditjen PP \& PL, 2007).

\section{Hasil Penelitian}

1. Jumlah Telur Nyamuk Aedes $s p$ yang terperangkat berdasarkan jenis atraktan

a. Air Bersih

Berdasarkan penelitian di Kelurahan Karangpucung, Kecamatan Purwokerto Selatan, Kabupaten Banyumas, dapat dilihat bahwa total jumlah telur nyamuk Aedes sp yang terperangkap dalam ovitrap berisi air bersih adalah 630 butir telur.

Air Bersih merupakan tempat berkembang biaknya nyamuk Aedes, nyamuk Aedes berkembang biak pada air jernih yang tidak beralaskan tanah seperti bak mandi, WC, tempayan, drum, dan barang-barang yang menampung air seperti kaleng, ban bekas, pot tanaman air, serta tempat minum burung (Widoyono, 2011,h.73).

Menurut Ditjen PP \& PL (2007), peletakkan telur nyamuk Aedes pada dinding tempat air atau pada bendabenda yang terapung di permukaan air.

b. Air Rendaman Udang Windu

$$
\text { Berdasarkan penelitian }
$$

Kelurahan Karangpucung, Kecamatan Purwokerto Selatan, Kabupaten Banyumas, dapat dilihat bahwa total jumlah telur nyamuk Aedes $s p$ yang terperangkap pada atraktan air rendaman udang windu yaitu 736 butir.

Air rendaman atau cucian udang mengandung sisa hasil metabolisme seperti feses, dan senyawa kimia lain, dalam bentuk gas maupun cair. Air rendaman udang windu misalnya, mengekskresi feses, ammonia dan karbon dioksia. Ekskresi ammonia berkisar antara 26 - 30 gram per kilogram pakan yang mengandung $35 \%$ pellet, sedangkan ekskresi $\mathrm{CO}_{2}$ 1,25 kali dari konsumsi oksigen. Kedua senyawa merupakan atraktan yang baik bagi nyamuk Aedes ( Sayono, 2008 ).

Atraktan dapat digunakan untuk mempengaruhi perilaku, memonitor atau menurunkan populasi nyamuk secara langsung, tanpa menyebabkan cedera bagi binatang lain dan manusia, dan tidak meninggalkan residu pada makanan atau bahan pangan (Sayono, 2008).

Menurut penelitian Sayono (2008), kemungkinan lain nyamuk meletakkan telur pada atraktan air rendaman udang windu adalah adanya zat, senyawa atau bahan atraktif lain yang terkandung dalam air rendaman udang yang tidak terdapat pada air bersih.

Hal ini sejalan dengan penelitian Sayono (2008) bahwa atraktan berisi air rendaman udang menghasilkan nyamuk Aedes yang terperangkap paling banyak yaitu LO (lethal Ovitrap) berisi air rendaman udang 13,29 ekor, sedangkan pada LO (lethal Ovitrap) berisi air rendaman jerami 4,20 dan pada LO (lethal Ovitrap) berisi air hujan (tanpa atraktan) 3,02 ekor. Atraktan air 
rendaman udang menghasilkan nyamuk Aedes terperangkap 3 - 4 kali lebih banyak daripada air rendaman jerami maupun air hujan, karena air rendaman udang mengandung kadar $\mathrm{CO}_{2}$ dan amonia yang cukup tinggi sehingga dapat menarik penciuman dan mempengaruhi nyamuk dalam memilih tempat bertelur. Senyawa tersebut dihasilkan dari proses fermentasi zat organik atau merupakan hasil ekskresi proses metabolisme.

c. Air Rendaman Udang Rebon

Berdasarkan hasil penelitian menunjukkan bahwa jumlah telur nyamuk yang terperangkap pada atraktan air rendaman udang rebon sebanyak 4 butir, berbeda dengan air rendaman udang windu yang menarik nyamuk dalam bertelur lebih banyak.

Menurut penelitian sayono (2008), air rendaman udang mengandung sisa hasil metabolisme seperti feses, dan senyawa kimia lain, dalam bentuk gas maupun cair. Air rendaman udang yang mengandung mengekskresi feses, ammonia dan karbon dioksia. Ekskresi ammonia berkisar antara 26 - 30 gram per kilogram pakan yang mengandung $35 \%$ pellet, sedangkan ekskresi $\mathrm{CO}_{2} \quad 1,25$ kali dari konsumsi oksigen. Kedua senyawa merupakan atraktan yang baik bagi nyamuk Aedes.

Air rendaman udang tersebut mengandung kadar $\mathrm{CO}_{2}$ dan amonia sehingga dapat menarik penciuman dan mempengaruhi nyamuk dalam memilih tempat bertelur. Senyawa tersebut dihasilkan dari proses fermentasi zat organik atau merupakan hasil ekskresi proses metabolisme. Nyamuk meletakkan telur pada atraktan air rendaman udang rebon karena adanya zat, senyawa atau bahan atraktif lain yang terkandung dalam air rendaman udang yang tidak terdapat pada air bersih (Sayono, 2008).

Tempat perkembangbiakan nyamuk betina umumnya bertelur dimana saja asal ada air, baik yang mengalir maupun air tergenang, tawar ataupun air asin, seperti air tawar/asin yang jernih/bersih ataupun yang keruh/busuk, air dalam kaleng bekas, tempurung maupun ban bekas, air dalam lubang pohon ataupun potongan bambu, air dalam ketiak daun (Dewi, 2011, h.58).
Indikasinya bahwa kandungan ammonia, dan $\mathrm{CO}_{2}$ yang ada pada air rendaman udang rebon lebih sedikit daripada kandungan air rendaman udang windu, sehingga kurang menarik penciuman nyamuk dalam mempengaruhi peletakkan telur nyamuk pada atraktan air rendaman udang rebon.

d. Perbedaan jumlah telur nyamuk Aedes sp pada modifikasi ovitrap

Jumlah telur nyamuk pada ovitrap yang berisi atraktan air rendaman udang windu didapatkan telur nyamuk Aedes sp paling banyak pada setiap periode pengamatan. Hasil pengamatan secara keseluruhan menunjukkan jumlah telur nyamuk yang terperangkap sebanyak 1370 butir, meskipun terjadi fluktuasi jumlah telur nyamuk Aedes sp yang terperangkap, namun ada konsistensi rata-rata 105 butir/hari. Jumlah telur nyamuk Aedes sp yang terperangkap pada ovitrap yang berisi atraktan air bersih sejumlah 630 butir, pada atraktan air rendaman udang windu 736 butir, serta pada atraktan air rendaman udang rebon berjumlah 4 butir.

Atraktan air rendaman udang windu dapat menarik nyamuk Aedes $s p$ untuk bertelur lebih banyak daripada air rendaman udang rebon padahal dalam karakteristiknya sama-sama tergolong udang yang mana memiliki kandungan amonia dan $\mathrm{CO}_{2}$ namun mungkin memiliki kuantitas dan kualitas yang berbeda sehingga menimbulkan daya tarik yang berbeda terhadap nyamuk Aedes sp. Berdasakan bionomik udang, udang windu hidup di air tawar sehingga tidak ada kandungan garam baik secara karakteristik maupun air rendamannya, sedangkan udang rebon hidup di air payau atau air asin sehingga karakteristik udang rebon tersebut asin termasuk air rendamannya.

Hasil penelitian ini bisa dikaitkan dengan adanya siklus gonotropik nyamuk artinya nyamuk betina menghisap darah untuk mematangkan telur secara sempurna (gravid) dengan siklus yang dimulai dari unfed (tidak ada darah dalam abdomen) hingga unfed. Siklus gonotropik ini disebut gonotropic association yaitu bila nyamuk menghisap darah, kemudian menahan telurnya menunggu datangnya hujan sampai 
ada genangan air untuk tempat bertelur dan selama itu nyamuk tidak menghisap darah lagi. Nyamuk penglihatannya kurang baik pada siang hari, mereka tertarik dengan aktifitas makhluk hidup dengan cara mendeteksi keberadaan $\mathrm{CO}_{2}$ pada saat bernafas, radiasi tubuh, dan bau keringat, bisa mendeteksi keberadaan makanan sejauh 100m. Dengan demikian semakin tinggi atau semakin banyaknya kandungan $\mathrm{CO}_{2}$ pada atraktan untuk menarik nyamuk di tempat tersebut (Aris Santjaka, 2013).

Menurut penelitian Dian Fergianto (2014), menunjukkan kemampuan beradaptasi larva Aedes aegypti sehingga dapat bertahan hidup di air tercemar dengan beberapa kadar BOD. Lima hari pada media dengan kadar BOD $47 \mathrm{mg} / \mathrm{l}$ sebesar 55\% larva Aedes aegypti hidup.

2. Jumlah Telur Nyamuk Aedes sp yang Terperangkap Berdasarkan Letak pemasangan ovitrap

Berdasarkan hasil uji statistik dalam letak pemasangan ovitrap secara signifikan didapatkan hasil $p=0,267 \geq a$ 0,05 artinya tidak ada perbedaan yang signifikan antara letak pemasangan ovitrap di luar rumah dengan di dalam rumah, namun secara absolut pemasangan ovitrap di luar rumah, jumlah telur nyamuk yang terperangkap lebih banyak yaitu 992 butir dengan prosentase $72 \%$ daripada pemasangan ovitrap di dalam rumah sebanyak 378 butir dengan prosentase $28 \%$.

Hal ini terjadi pada kelompok ovitrap dengan atraktan yang berbeda-beda pada setiap periode pengamatan. Penelitian ini menunjukkan aktifitas bertelur (oviposition) nyamuk Aedes sp lebih banyak di luar rumah.

Kondisi lingkungan fisik rumah responden sebagian besar terdapat barang bekas dengan genangan air, tempat gelap dan dipengaruhi oleh musim sangat cocok untuk berkembang biak nyamuk. Kondisi lingkungan fisik pada rumah responden 1 letakpemasangan ovitrap di luar rumah berposisi dekat dinding memiliki kondisi lembab, sedangkan di dalam rumah letak pemasangan berada di gudang penyimpanan barang bekas dengan kondisi gelap dan lembab. Kondisi lingkungan fisik rumah responden 2 letak pemasangan di luar rumah berada dekat dengan semak-semak samping rumah, sedangkan di dalam rumah diletakkan di tempat yang gelap dibawah tempat duduk. Kondisi lingkungan fisik rumah responden 3 letak pemasangan di luar rumah berada disamping dinding rumah, sedangkan di dalam rumah berada dekat dengan barang-barang bekas dengan kondisi ruangan yang gelap dan lembab. Kondisi lingkungan fisik rumah responden 4 letak pemasangan ovitrap di luar rumah berada dekat dengan tempat duduk yang jarang terpakai dengan kondisi lembab, sedangkan letak pemasangan di dalam rumah berada dekat dengan barang-barang yang tidak terpakai atau bekas. Kemudian kondisi lingkungan fisik rumah responden 5 letak pemasangan ovitrap di luar rumah berada dekat semak-semak dan barang-barang bekas yang tidak terpakai, sedangkan di dalam rumah dekat dengan penyimpanan barang yang tidak terpakai serta tempat cucian kotor.

Kondisi-kondisi tersebut memungkinkan sebagai breeding place dan potensial breeding place bagi nyamuk Aedes sp. Menurut Ditjen PP \& PL (2007), kebiasaan nyamuk beristirahat menunggu waktu bertelur pada tempattempat yang gelap, lembab dan sedikit angin. Beberapa faktor lingkungan lain,diantaranya letak geografis dan iklim secara tidak langsung akan mempengaruhi populasi vektor nyamuk (Cecep, 2011).

Hal ini sesuai dengan penelitian Sayono (2008) bahwa Rerata nyamuk Aedes yang terperangkap menurut letak pemasangan LO (Lethal Ovitrap), nyamuk Aedes lebih banyak terperangkap LO (Lethal Ovitrap) di luar rumah, karena kondisi lingkungan fisik diluar rumah lebih mendukung. Beberapa hasil penelitian menemukan bahwa telur Aedes lebih banyak yang terperangkap pada ovitrap yang dipasang di luar rumah, meskipun banyak penelitian lainnya menemukan hasil yang sebaliknya, tetapi penting untuk diperhatikan bahwa memasang ovitrap di luar rumah dapat produktif dalam mengendalikan populasi Aedes.

3. Jumlah Telur Nyamuk Aedes sp yang Terperangkap berdasarkan waktu pengamatan

Secara umum, jumlah telur nyamuk Aedes sp yang terperangkap pada ovitrap mengalami penurunan seiring waktu pengamatan. Hal tersebut dipengaruhi oleh kondisi cuaca yang tidak menentu. Jumlah telur nyamuk Aedes $s p$ terperangkap pada air bersih, air rendaman udang windu, dan air 
rendaman udang rebon memiliki perbedaan yaitu sebagai berikut

a. Waktu pengamatan ovitrap pada atraktan air bersih, paling banyak didapatkan telur pada pengamatan hari kelima dengan jumlah 206 butir dan paling sedikit hasil pengamatan jumlah telur nyamuk pada hari ketiga yaitu 5 butir, pengamatan jumlah telur nyamuk pada atraktan air bersih mengalami fluktuasi, $\mathrm{H}-1$ tinggi dengan 72 butir, H-2 164 butir, H-3 5 butir, H-4 76 butir, H-5 206 butir, H-6 98 butir, dan $\mathrm{H}-7$ menjadi 9 butir.

b. Pada atraktan air rendaman udang windu hasil pengamatan paling banyak pada hari keenam dengan jumlah telur 206 butir, sedangkan paling sedikit jumlah telur pada hari pertama yaitu 4 butir, pengamatan jumlah telur pada atraktan ini mengalami fluktuasi yaitu pada $\mathrm{H}-14$ butir, $\mathrm{H}-2173$ butir, $\mathrm{H}-397$ butir, H-4 7 butir, H-5 157 butir, H-6 206 butir, dan $\mathrm{H}-7$ turun menjadi 92 butir.

c. Hasil pengamatan atraktan air rendaman udang rebon paling banyak terjadi di hari terakhir dengan jumlah 4 butir, sedangkan hasil pengamatan sebelumnya sama sekali tidak ditemukan telur nyamuk yang terperangkap.

Keadaan kondisi lingkungan ratarata pada $\mathrm{H}-2, \mathrm{H}-5$, dan $\mathrm{H}-6$ dapat menarik jumlah telur nyamuk lebih banyak daripada hari yang lainnya. Keadaan tersebut dapat dipengaruhi oleh faktor sanitasi lingkungan sekitar rumah responden dan faktor lingkungan fisik yang memungkinkan adanya breeding dan potensial breeding nyamuk Aedes sp.

Suhu pada hari $\mathrm{H}-2, \mathrm{H}-5$, dan $\mathrm{H}-6$ berkisar antara $25^{\circ} \mathrm{C}-30^{\circ} \mathrm{C}$ (Sofiyatul, 2014) masih cocok untuk perkembang biakan dan adaptasinya nyamuk, padahal suhu optimum untuk perkembangan nyamuk rata-rata yaitu $25^{\circ} \mathrm{C}-27^{\circ} \mathrm{C}$. Nyamuk dapat bertahan hidup dalam suhu rendah, tetapi proses metabolismenya menurun atau bahkan terhenti bila suhu turun sampai dibawah suhu kritis, pada suhu yang sangat tinggi akan mengalami perubahan proses fisiologinya. Pertumbuhan nyamuk akan terhenti sama sekali bila suhu kurang dari $10^{\circ} \mathrm{C}$ atau lebih $40^{\circ} \mathrm{C}$. Toleransinya terhadap suhu tergantung pada species nyamuknya, tetapi pada umumnya suatu species tidak akan tahan lama bila suhu lingkungan meninggi $5^{\circ} \mathrm{C}-6^{\circ} \mathrm{C}$ diatas, dimana species secara normal dapat beradaptasi (Ditjen PP \& PL, 2007).

Pada kelembaban kurang dari $60 \%$ umur nyamuk akan menjadi pendek sehingga tidak cukup untuk siklus pertumbuhan parasit di dalam tubuh nyamuk (Ditjen PP \& PL, 2007). Dalam 7 hari pengamatan rata-rata kelembaban berkisar antara 75\%-95\% (Sofiyatul, 2014), sehingga jumlah telur nyamuk pada waktu pengamatan tersebut dapat diperoleh banyak karena ada perkembangan nyamuk.

Hasil pengukuran tersebut tidak sesuai dengan jumlah telur nyamuk yang didapatkan, kemungkinan nyamuk sudah dapat beradaptasi dengan kondisi tesebut atau karena alat pengukuran dan hasil baca yang kurang akurat.

Menurut penelitian Sayono (2008), keadaan tersebut terjadi karena dua alasan terpenting, yaitu penelitian yang dilakukan pada perubahan musim penghujan ke musim kemarau sehingga secara alamiah populasi nyamuk Aedes $s p$ berkurang akibat berkurangnya tempat perindukan, dan populasi nyamuk Aedes sp di lokasi penelitian semakin sedikit karena regenerasi terganggu akibat penggunaan ovitrap.

4. Faktor Yang Mempengaruhi

Berdasarkan hasil pengumpulan data menggunakan kuesioner terhadap responden maka dapat diketahui data, frekuensi, dan persentasi yang dapat dijadikan bahan analisis, interprestasi atau pembahasan terhadap hasil yang sudah dilakukan yaitu sebagai berikut:

a. Pengasapan

Pemberantasan terhadap nyamuk dewasa dilakukan dengan cara spraying (pengasapan=fogging) dengan insektisida. Hal ini dilakukan mengingat kebiasaan nyamuk yang hinggap dan suka bersembunyi di tempat gelap seperti di dalam rumah atau gedung. Selain itu nyamuk Aedes sp juga menyukai tempat yang lembab dan ditempat yang tersembunyi seperti pada pakaian yang digantung. Karena itu tidak dilakukan pengasapan pada dinding rumah seperti pada pemberantasan penyakit malaria.

Wawancara kepada responden bertujuan untuk mengetahui upaya pengendalian dengan cara pengasapan atau fogging yang dilaksanakan untuk mengendalikan populasi vektor penyakit DBD di Kelurahan Karangpucung.

Berdasarkan hasil penelitian ini, dapat dilihat bahwa dari 5 responden $100 \%$ tidak adanya upaya 
pengasapan pada waktu penelitian dilaksanakan terutama pada rumah responden tersebut.

Menurut Cecep

pengendalian dengan cara pengasapan/ fogging dilakukan sebagai pemberantasan nyamuk dewasa penyakit DBD. Hal ini dilakukan mengingat kebiasaan nyamuk penyebab DBD yang hinggap pada benda-benda tergantung, karena itu tidak dilakukan penyemprotan didinding rumah seperti pada pemberantasan penyakit malaria.

Insektisida yang lazim dipakai dalam program pemberantasan demam berdarah ialah malathion (untuk membunuh nyamuk dewasa atau adultsida). Malathion digunakan dengan cara pengasapan (thermal fogging) atau pengabutan.

Menurut Sayono tahun 2008, Pada pemberantasan vektor demam berdarah, cara penyemprotan pada dinding-dinding tidak dapat digunakan karena nyamuk Aedes tidak suka hinggap di dinding, melainkan pada benda-benda yang tergantung seperti kelambu, pakaian yang tergantung dan sebagainya.

b. Abatisasi

Wawancara kepada responden bertujuan untuk mengetahui upaya pengendalian dengan abatisasi yang dilaksanakan pada lokasi penelitian tersebut untuk mengurangi jumlah populasi nyamuk.

Berdasarkan hasil penelitian ini, dapat dilihat bahwa dari 5 responden $100 \%$ tidak adanya abatisasi pada waktu penelitian dilaksanakan, sehingga berpengaruh pada populasi nyamuk di Kelurahan Karangpucung.

Menurut Widoyono tahun 2011, abatisasi yang selektif merupakan kegiatan penaburan abate/larvasida kedalam bak penampung air yang positif terdapat jentik, hal ini dilakukan sebagai program pemberantasan sarang nyamuk.

c. Penggunaan Insektisida Rumah Tangga

Wawancara kepada responden bertujuan untuk mengetahui penggunaan insektisida rumah tangga pada lokasi penelitian sehingga dapat mengurangi jumlah populasi nyamuk.

Berdasarkan hasil penelitian ini, dapat dilihat bahwa dari 5 responden $60 \%$ tidak menggunakan insektisida rumah tangga atau biasa disebut obat anti nyamuk, sedangkan $40 \%$ responden penelitian menggunakan obat anti nyamuk.

Penggunaan insektisida rumah tangga dapat mempengaruhi populasi nyamuk di Kelurahan Karangpucung, oleh karena itu perkembang biakan nyamuk di rumah responden tertentu yang menggunakan insektisida lebih sedikit.

d. Pemberantasan Sarang Nyamuk

Wawancara kepada responden bertujuan untuk mengetahui upaya pengendalian dengan abatisasi yang dilaksanakan pada lokasi penelitian tersebut untuk mengurangi jumlah populasi nyamuk.

Berdasarkan hasil penelitian ini, dapat dilihat bahwa dari 5 responden $100 \%$ tidak adanya abatisasi pada waktu penelitian dilaksanakan.

PSN merupakan pemberantasan vektor tanpa insektisida. Cara ini dilakukan dengan membersihkan atau meniadakan sarang-sarang nyamuk, dengan cara $3 \mathrm{M}$ yaitu Menguras bak mandi, menutup tempat penampungan air untuk keperluan sehari- hari, dan mengubur atau menyingkirkan barang-barang bekas yang dapat menampung air (Cecep, 2011).

Lokasi responden yang diteliti masalah pemberantasan sarang nyamuk melalui kegiatan $3 \mathrm{M}$ ( Menguras bak penampungan air, menutup tempat penampungan air, dan mengubur barang bekas) tidak dilaksanakan dengan baik. Terlihat dari banyaknya barang- barang bekas yang dapat menampung air hujan berserakan di sekitar rumah responden. Hal tersebut mengakibatkan banyaknya nyamuk yang berkembang biak di daerah tersebut dan menyebarkan penyakit demam berdarah.

\section{Hasil Uji Statistika}

Hasil uji statistik One Way Anova diperoleh signifikan $p=0,002$ karena $p=0,002$ $\leq$ a 0,05 maka syarat homogenitasnya tidak terpenuhi, kemudian alternative uji ini menggunakan uji Kruskal wallis yang diperoleh secara signifikan $\mathrm{p}=0,007 \leq \alpha$ 0,05 , artinya ada perbedaan secara signifikan antara jumlah telur nyamuk Aedes sp yang terperangkap pada masing- masing atraktan.

Dalam uji statistik Kruskal Wallis ini dicari perbedaan dari masing- masing variabel dengan variabel lain, maka dilanjutkan menggunakan analisis non parametrik, 2 
sampel independen dengan uji $U$ Mann Whitney yaitu sebagai berikut :

1. Kelompok 1 \& 2 yaitu air bersih dan air rendaman udang windu hasil signifikan $\mathrm{p}=0,631 \geq \alpha \quad 0,05$ artinya kelompok tersebut tidak ada perbedaan yang signifikan antara air besih dan air rendaman udang windu sebagai atraktan nyamuk Aedes sp, namun secara absolut jumlah telur nyamuk yang berisi atraktan air rendaman udang windu sebanyak 736 butir lebih banyak dibandingkan air bersih yaitu 630 butir.

2. Kelompok 1 \& 3 yaitu air bersih dan air rendaman udang rebon hasil signifikan $\mathrm{p}=0,009 \leq \alpha \quad 0,05$ artinya kelompok ter sebut ada perbedaan secara signifikan antara air bersih dengan air rendaman udang rebon. Jumlah telur nyamuk pada air bersih sebanyak 630 butir dan air rendaman udang rebon sebanyak 4 butir.

3. Kelompok 2 \& 3 yaitu variabel air rendaman udang windu dan air rendaman udang rebon hasil signifikan $p=0,009 \leq \alpha$ 0,05 artinya kelompok tersebut ada perbedaan secara signifikan antara air rendaman udang windu dan air rendaman udang rebon. Jumlah telur pada air rendaman udang windu sebanyak 736 butir, sedangkan pada air rendaman udang rebon sebanyak 4 butir.

Banyaknya nyamuk Aedes sp yang terperangkap menunjukkan jumlah telur yang diletakkan ovitrap berisi air rendaman udang windu lebih banyak daripada ovitrap yang berisi jenis atraktan lainnya. Dengan kata lain, atraktan air rendaman udang windu memiliki daya tarik (atraktansi) yang lebih kuat daripada air rendaman udang rebon dan air bersih.

\section{SIMPULAN DAN SARAN}

\section{A. Simpulan}

Berdasarkan penelitian yang telah dilakukan di Kelurahan Karangpucung, kecamatan Purwokerto Selatan, kabupaten Banyumas tahun 2014 dapat diambil kesimpulan bahwa :

1. Perbandingan jumlah telur nyamuk Aedes sp yang terperangkap pada ovitrap berdasarkan jenis atraktan adalah jumlah telur pada ovitrap yang berisi atraktan air rendaman udang windu sebanyak 736 butir, ovitrap berisi air bersih sebanyak 630 butir dan paling sedikit pada ovitrap berisi air rendaman udang rebon yaitu 4 butir, sehingga atraktan air rendaman udang windu paling menarik nyamuk lebih banyak unruk meletakkan telurnya tetapi selisih sedikit dengan atraktan air bersih.

2. Perbandingan jumlah telur nyamuk Aedes sp yang terperangkap pada ovitrap berdasarkan letak pemasangan nilai signifikan $p=0,285 \geq \alpha \quad 0,05$ artinya tidak ada perbedaan yang signifikan antara letak pemasangan ovitrap di luar rumah dan di dalam rumah. Jumlah paling banyak nyamuk terperangkap pada luar rumah responden sebanyak 992 butir dengan prosentase $72 \%$ sedangkan ovitrap di dalam rumah sebanyak 378 butir dengan prosentase sebesar $28 \%$.

3. Perbandingan jumlah telur nyamuk Aedes $s p$ yang terperangkap pada ovitrap berdasarkan waktu pengamatan adalah jumlah telur nyamuk pada atraktan air bersih $\mathrm{H}-1$ tinggi dengan 72 butir, $\mathrm{H}-2164$ butir, $\mathrm{H}-35$ butir, $\mathrm{H}-476$ butir, H-5 206 butir, H-6 98 butir, dan $\mathrm{H}-$ 7 menjadi 9 butir, sedangkan pada air rendaman udang windu $\mathrm{H}-14$ butir, $\mathrm{H}-2$ 173 butir, $\mathrm{H}-397$ butir, $\mathrm{H}-47$ butir, $\mathrm{H}-5$ 157 butir, H-6 206 butir, kemudian H-7 turun menjadi 92 butir, dari hasil pengamatan air bersih dan air rendaman udang windu keduanya mengalami fluktuasi. Pada air rendaman udang rebon mengalami kenaikan jumlah telur pada pengamatan terakhir yaitu 4 butir. $\mathrm{H}-2, \mathrm{H}-$ 5 , dan $\mathrm{H}-6$ didapatkan telur lebih banyak dari hari pengamatan lainnya.

4. Berdasarkan hasil penelitian ini diperoleh hipotesis bahwa Ha diterima artinya ada pengaruh modifikasi ovitrap terhadap jumlah telur nyamuk Aedes $s p$ yang terperangkap.

\section{B. Saran}

1. Bagi masyarakat

a. Masyarakat hendaknya mendukung dan berpartisipasi dalam program pemutusan mata rantai penularan penyakit DBD melalui penerapan pemasangan ovitrap dalam pemantauan kepadatan Aedes sp oleh petugas kesehatan untuk mengetahui tingkat kerawanan suatu wilayah.

b. Masyarakat hendaknya berperan aktif merubah kebiasaan buruk dengan melakukan PSN yaitu kegiatan "3M Plus" Menguras bak mandi, menutup tempat penampungan air untuk keperluan sehari-hari, dan mengubur atau menyingkirkan barang-barang bekas yang dapat menampung air dan penggunaan reppelent, kelambu insektisida serta memanfaatkan binatang predator yang mudah didapat seperti ikan cupang/tempalo, ikan kepala timah, ikan gupi dan lain-lain. 
Ikan tersebut dimasukan ke dalam bak mandi atau tempat penampungan air lainnya. Hal ini diharapkan ikanikan tersebut memakan larva atau jentik yang ada di dalam tempat penampungan air.

2. Bagi Instansi Kesehatan

a. Dinas Kesehatan mensosialisasikan penggunaan ovitrap yang berisi air bersih untuk pemantauan kepadatan nyamuk Aedes sp

b. Mengaktifkan kader-kader kesehatan yang berada di Kelurahan untuk menggalang partisipasi masyarakat dalam mensukseskan program pemberantasan sarang nyamuk (PSN) sehingga dapat memutus mata rantai penularan penyakit DBD

3. Bagi Peneliti Lain

Kelemahan dari penelitian ini, peneliti tidak mengukur kepadatan populasi nyamuk sebelum dan sesudah aplikasi ovitrap, sehingga tidak diketahui penurunan kepadatan nyamuk sebagai hasil dari aplikasi ovitrap tersebut. Oleh karena itu perlu dilakukan penelitian lanjutan dengan melakukan pengukuran kepadatan nyamuk atau index jentik $(H, C l, B I)$ pada daerah yang akan diteliti sehingga terlihat bahwa ovitrap tersebut dapat mengendalikan atau menekan kepadatan nyamuk disuatu wilayah.

\section{DAFTAR PUSTAKA}

Arif, Sumantri, 2013, Edisi Revisi Kesehatan Lingkungan, Jakarta : Kencana Prenada Media Group

Arikunto, S, 2005, Manajeman Penelitian, Jakarta : Rineka Cipta

2006, Prosedur Penelitian Suatu Pendekatan Praktik, Jakarta : Rineka Cipta

Aris, Santjaka, 2008, Bio Statistik, Purwokerto : Global Internusa

2013, Malaria Pendekatan Model Kausalitas, Purwokerto : Numed

Budiman, Chandra, 2007, Pengantar Kesehatan Lingkungan, Jakarta : Penerbit Buku Kedokteran EGC

$\begin{array}{ccc}\text { Cecep,Dani } 2011, \quad \text { Vektor } & \begin{array}{c}\text { Penyakit } \\ \text { Tropis, } \\ \text { Publishing }\end{array}\end{array}$

Departemen Kesehatan Republik Indonesia, 2009, Rencana Pembangunan Jangka Panjang Bidang Kesehatan 2005-2025 (RPJP-K), Jakarta : Depkes RI

Departemen Kesehatan R.I. Direktorat Jenderal Pengendalian Penyakit Dan Penyehatan Lingkungan (DIT.JEN.PP\&PL), 2007, Ekologi dan Aspek Perilaku Vektor, Jakarta : DIT.JEN.PP \& PL

Departemen Kesehatan R.I. Direktorat Jenderal Pengendalian Penyakit Dan Penyehatan Lingkungan (DIT.JEN.PP\&PL), 2007, Survey Entomologi Demam Berdarah Dengue, Jakarta : DIT.JEN.PP \& PL

Departemen Kesehatan RI, 2009, Rencana Pembangunan Jangka Panjang Bidang Kesehatan 2005 - 2025, Jakarta : Depkes RI

Depkes RI, 2004, Pedoman Ekologi dan Aspek Perilaku Vector, Jakarta : Ditjend PPM \& PL

Depkes RI, 2007, Survai Entomologi Demam Berdarah Dengue, Jakarta : Ditjen PP \& PL

Dewi, Susanna \& Sumbiring, 2011, Entomologi Kesehatan (Artropoda Pengganggu Kesehatan dan Parasit yang Dikandungannya), Jakarta : Universitas Indonesia

Dian, Fergianto, 2014, Komparasi Daya Tahan Hidup Larva aedes aegypti Pada Beberapa Kadar BOD Tahun 2014, Purwokerto : Kementrian Kesehatan RI Politeknik Kesehatan Kemenkes Semarang Jurusan Kesehatan Lingkungan Purwokerto

Didik, Sarudji, 2010, Kesehatan Lingkungan, Bandung : Karya Putra Darwati

Dinas Kesehatan Kabupaten Banyumas, 2013, Data Endemisitas DBD Kabupaten Banyumas Tahun 2013, Banyumas : Dinas Kesehatan Kabupaten Banyumas

Djamaluddin, Ramlan, 2013, Petunjuk Praktis Penulisan Penelitian Eksplanatif, Purwokerto : UPT Percetakan dan Penerbitan

Hidayat, A, 2007, Metode Penelitian Kebidanan dan Teknik Analisa data, Jakarta : 
Salemba Medika, 2010, Metode Penelitian Kesehatan Paradigma kuantitatif, Jakarta : Healt Books

Karangpucung, 2014, Profil Kelurahan Karangpucung, Purwokerto Selatan, Banyumas 2014, Banyumas : Karangpucung

Kementrian Kesehatan RI, 2012, Profil Kesehatan Indonesia 2012, Jakarta: Kemenkes RI

Notoatmodjo, Soekidjo, 2010, Metodologi Penelitian Kesehatan, Jakarta : Rineka Cipta

Puskesmas Purwokerto Selatan, 2013, Laporan Kasus Penyakit Demam Berdarah Dengue Periode Januari Desember 2013, Banyumas : Puskesmas Purwokerto Selatan

Rakkang, dkk, 2013, Efektifitas Lethal Ovitrap Ataktan Terhadap Penurunan Kepadatan Larva Aedes aegypti di Kelurahan Adatongeng Kecamatan Turikale Kabupaten Maros, http://repository.unhas.ac.id/handle/1234 56789/6068, Diakses tanggal 2 juni 2014

Ririh, Yudhastuti, 2011, Pengendalian Vektor dan Rodent, Surabaya : Pustaka Melati

Rozi, 2008, Penerapan Budidaya Udang Ramah Lingkungan Dan Berkelanjutan Melalui Aplikasi Bakteri Antagonis Untuk Biokontrol Vibriosis Udang Windu (Penaeus monodon), Yogyakarta : Universitas Gadjah Mada

\footnotetext{
Salmiyatun, 2004, Pencegahan Pengendalian Dengue \& Demam berdarah Dengue, Jakarta : Penerbit Buku Kedokteran EGC
}

Sayono, 2008, Pengaruh Penerapan Lethal Ovitrap yang Dimodifikasi Terhadap Jumlah Nyamuk Aedes yang Terperangkap, Tesis : Universitas Dipenogoro
Pengaruh Modifikasi Ovitrap Terhadap Jumlah Nyamuk Aedes Yang Terperangkap, Tesis : Universitas Dipenogoro

Setiawan, A \& Saryono, 2010, Metodologi Penelitian kebidanan, Jakarta : Nuha Medika

Soedarto, 2009, Penyakit Menular Di Indonesia Cacing, Protozoa, Virus, Jamur, Jakarta : CV Sagung Seto

Soegeng, Soegijanto, 2008, Demam Berdarah Dengue Edisi Kedua, Surabaya : Airlangga University Press

Sofiyatul, Mardiyah, 2014, Pengaruh Berbagai Konsentrasi Air Rendaman Jerami Sebagai Atraktan Terhadap Jumlah Telur Nyamuk Aedes sp Yang Terperangkap DI Rw 04 Kelurahan Karangpucung Kecamatan Purwokerto Selatan Kabupaten Banyumas Tahun 2014, Purwokerto: Kementrian Kesehatan RI Politeknik Kesehatan Kemenkes Semarang Jurusan Kesehatan Lingkungan Purwokerto

Stalker, Peter, 2008, Millenium Development Goals, Jakarta : Bappenas

Supratman, Sukowati, 2010, Bulletin Jendela Epidemiologi Masalah Vektor Demam Berdarah Dengue DBD Dan Pengendaliannya Di Indonesia, Jakarta : Pusat Data Dan Surveilans Epidemiologi Kemenkes RI

Tanjung, Nadya. U, 2011, Hubungan Difusi Inovasi Dengan Pemanfaatan Ovitrap Oleh Ibu Rumah Tangga di Kelurahan Sei era Hilir I Kecamatan Medan Perjuangan Kota Medan Tahun 2010, Skripsi, Medan : Universitas Sumatera

Widoyono, 2011, Penyakit Tropis Epidemiologi, Penularan, Pencegahan \& Pemberantasannya, Jakarta Erlangga 